\title{
Selective IgA Deficiency
}

\author{
Leman Yel
}

Received: 13 November 2009/Accepted: 20 November 2009/Published online: 26 January 2010

(C) The Author(s) 2010. This article is published with open access at Springerlink.com

\begin{abstract}
Introduction Immunoglobulin A ( $\operatorname{IgA})$ deficiency is the most common primary immunodeficiency defined as decreased serum level of IgA in the presence of normal levels of other immunoglobulin isotypes. Most individuals with IgA deficiency are asymptomatic and identified coincidentally. However, some patients may present with recurrent infections of the respiratory and gastrointestinal tracts, allergic disorders, and autoimmune manifestations. $\operatorname{IgA}$ and Its Functions Although $\operatorname{IgA}$ is the most abundant antibody isotype produced in the body, its functions are not clearly understood. Subclass IgA1 in monomeric form is mainly found in the blood circulation, whereas subclass $\operatorname{IgA} 2$ in dimeric form is the dominant immunoglobulin in mucosal secretions. Secretory $\operatorname{IgA}$ appears to have prime importance in immune exclusion of pathogenic microorganisms and maintenance of intestinal homeostasis. Despite this critical role, there may be some compensatory mechanisms that would prevent disease manifestations in some IgA-deficient individuals.

Pathogenesis In IgA deficiency, a maturation defect in B cells to produce IgA is commonly observed. Alterations in transmembrane activator and calcium modulator and cyclophilin ligand interactor gene appear to act as diseasemodifying mutations in both $\operatorname{IgA}$ deficiency and common variable immunodeficiency, two diseases which probably lie in the same spectrum. Certain major histocompatibility complex haplotypes have been associated with susceptibility to IgA deficiency.

Conclusion The genetic basis of IgA deficiency remains to be clarified. Better understanding of the production and
\end{abstract}

L. Yel $(\bowtie)$

University of California, Irvine,

Irvine, CA, USA

e-mail: lyel@uci.edu function of $\operatorname{IgA}$ is essential in elucidating the disease mechanism in IgA deficiency.

Keywords IgA · function · immunodeficiency · pathogenesis

\section{Introduction}

Immunoglobulin (Ig) A deficiency (OMIM 137100) is defined as decreased or absent level of serum $\operatorname{IgA}$ in the presence of normal serum levels of IgG and IgM in a patient older than 4 years of age, in whom other causes of hypogammaglobulinemia have been excluded $[1,2]$. In general, serum IgA level of less than $7 \mathrm{mg} / \mathrm{dL}(0.07 \mathrm{~g} / \mathrm{L})$ is considered as selective IgA deficiency since this concentration is the lowest detectable limit established by most of the laboratories. When serum IgA level is higher than $7 \mathrm{mg} / \mathrm{dL}$ but two standard deviations below normal for age, the condition may be referred to as partial IgA deficiency, which is quite common. The threshold of 4 years of age is used to avoid premature diagnosis of IgA deficiency which may be transient in younger children due to delayed ontogeny of IgA system after birth.

In here, selective IgA deficiency, with an emphasis on functions of IgA and disease pathogenesis, along with its epidemiology, clinical manifestations, disease associations, treatment approaches, and prognosis will be reviewed.

\section{Immunoglobulin A and Its Functions}

First described in serum in 1953, IgA is the most abundant antibody isotype produced in the body [3-7]. It is the second dominant isotype in the blood circulation following IgG. It can be found in both monomeric and polymeric forms. 
Circulating $\operatorname{IgA}$ is in monomeric form, whereas secretory $\operatorname{IgA}$, in the mucosal secretions of respiratory, intestinal, and genitourinary systems, is dimeric $[4,6,7]$. The monomeric structure of serum IgA has two heavy chains, each consisting of one variable and three constant regions, and two light chains, each of which is made up of one variable and one constant region. In humans, there are two subclasses of IgA: IgA1 and IgA2, constant heavy chains of which are encoded by two separate $\alpha 1$ and $\alpha 2$ genes on chromosome 14 [5-7]. The main structural difference between them is that IgA2 has a shorter hinge region which may render this isotype more resistant to bacterial proteases in the lumen of gastrointestinal or respiratory systems [8].

The function of serum $\operatorname{IgA}$ in the systemic immune response has not been clearly understood. Monomeric IgA in the circulation does not fix the classical pathway of the complement. However, it may have a role in activation of phagocytic system by means of the $\mathrm{FcR} \alpha$ receptors $[5,7,9]$. It has been proposed that serum $\operatorname{IgA}$ binds to $\mathrm{FcR} \alpha$ receptor on the monocytes and granulocytes; thereby, immune complexes formed by foreign antigens and IgA are cleared from the circulation by the phagocytic system without activating the complement system and without causing inflammation [10, 11]. Serum IgA may also have a role in controlling the immune system through inhibition of neutrophil chemotaxis by binding to other inhibitory proteins such as $\alpha$-1-antitrypsin and forming complexes $[5,7]$.

IgA, which is mostly in dimeric form, is the dominant immunoglobulin in luminal secretions comprising more than two thirds of total IgA production in the body $[8,12,13]$. Being more resistant to proteolytic activity of the bacteria, $\operatorname{IgA} 2$ is the main IgA subclass found in secretions, although
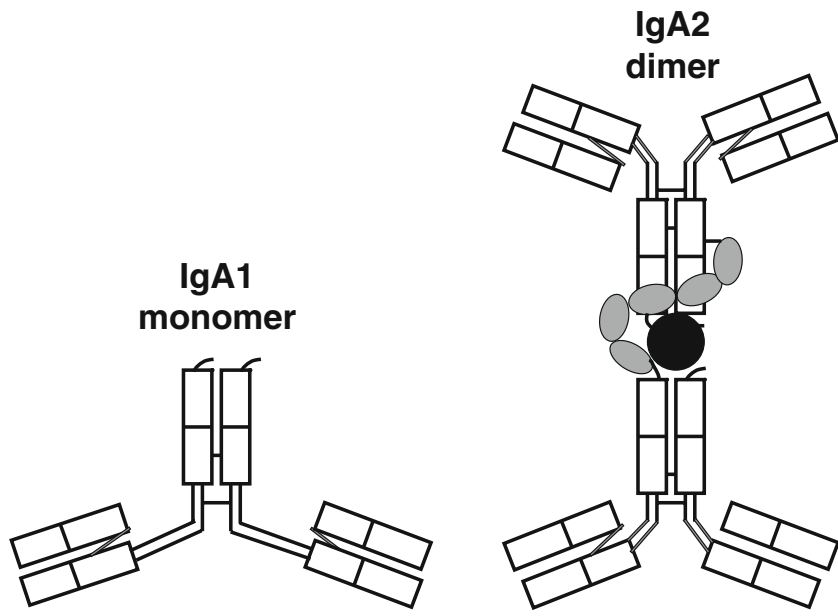

Fig. 1 Models of a monomeric IgA (left) and a dimeric secretory IgA (right). The monomer contains IgA1 subclass, whereas the dimer comprises two IgGA2 subclass monomers. The black circle denotes the joining $(J)$ chain. The gray chain of five oval links indicates the secretory piece. Note the shorter hinge region in IgA2 [8]. Modified from [22] both IgA subclasses can form dimers by covalent interaction with a joining $(\mathrm{J})$ chain attached to the terminal constant region on the Fc portion. The secretory $\operatorname{IgA}$ dimer contains a secretory component which is actually the secreted component of the polymeric immunoglobulin receptor located on the basolateral surface of the mucosal epithelial cell $[13,14]$ (Fig. 1). More than $95 \%$ of secretory IgA is produced locally. In the gastrointestinal system, organized Payer's patches or isolated lymphoid follicles as well as nonorganized lamina propria can be sites for local IgA production by $\mathrm{T}$ cell-dependent as well as $\mathrm{T}$ cell-independent mechanisms [15-17]. Intestinal epithelial cells, dendritic cells, and local stromal cells may be contributing to $\mathrm{T}$ cellindependent production of $\operatorname{IgA}$ locally by secreting thymic stromal lymphopoietin, interleukin (IL)-6, interleukin-10, tumor necrosis factor-alpha, transforming growth factor beta (TGF- $\beta 1$ ), B-cell activating factor (BAFF), and a proliferation-inducing ligand (APRIL) [16].

Mucosal membranes in the body cover an approximate area of 200-400 $\mathrm{m}^{2}$ harboring an estimate of 15,000-36,000 species and 1,800 genera of microbiota [18-21]. Thus, the total number of prokaryotic cells exceeds the total number of eukaryotic cells in the body. Bacteria endogenous to the intestinal tract, oral cavity, and respiratory and genital tracts are coated with secretory IgA. As a result, the epithelial adherence and penetration of bacteria are limited, and the bacteria are confined to the mucosal surfaces [20]. The IgA coating of bacteria is traditionally considered to be through adaptive immunity by Fab-mediated antigen-specific binding. Recently, it has been proposed that there is a link between the specific antibody-dependent protection and the innate glycan-mediated mucosal immunity by means of $\mathrm{N}$ - and $\mathrm{O}$-glycans of secretory IgA. It is likely that glycan-mediated interactions in concert with Fab-mediated polyreactivity enforce protective functions of secretory $\operatorname{IgA}[19,20,22,23]$. Despite this critical role of secretory IgA, surprisingly, some individuals with selective IgA deficiency are asymptomatic. The diagnosis of $\operatorname{IgA}$ deficiency depends on the measurement of IgA concentration in serum. Secretory IgA level is not determined; therefore, it is possible that the individuals diagnosed with selective IgA deficiency may still have some IgA in the mucosal systems enough to provide some protective functions. In addition, in most IgA-deficient patients, seemingly as a compensatory mechanism, production of secretory $\operatorname{IgM}$ is increased [24, 25]. IgA and $\operatorname{IgM}$ have evolutionary, structural, and functional similarities: homologies between the primary constant chain domains and the tail pieces, presence of a $\mathrm{J}$ chain in both, formation of polymers, ability to bind the basolateral polymeric Ig receptor on mucosal epithelial cell, and thereby forming secretory immunoglobulin molecule that contains the epithelial secretory component. The glycan moieties are 
also similar in $\operatorname{IgA}$ and $\operatorname{IgM}$ molecules [26-28]. However, there are also some IgA-deficient patients who do not exhibit compensatory increase in secretory IgM [29].

Most of the commensal bacteria are located in the gastrointestinal tract $[15,16]$. Therefore, maintenance of intestinal homeostasis is of prime importance. This homeostasis is achieved by means of immune defense mechanisms, in which secretory IgA has a central role. Growing body of evidence suggests that protective role of secretory $\operatorname{IgA}$ in the gastrointestinal system is not only through immune exclusion of bacteria [16-20]. In mice, it has been shown that secretory IgA is also critical in regulating bacterial communities of the intestinal lumen. Excessive expansion of anaerobic bacteria in the entire proximal intestinal system due to lack of secretory $\operatorname{IgA}$ has been reported in activation-induced cytidine deaminase knockout mice [30]. Similar aberrant anaerobic expansion is also observed in other mice with $\operatorname{IgA}$ deficiency, e.g., RAG2 -/-, SCID mice [31, 32]. This type of change in the intestinal microbial ecology may cause activation of mucosal immune cells including intraepithelial lymphocytes, cells of the isolated lymphoid follicles, Peyer's patches, and mesenteric lymph nodes. In addition, this activation status may become systemic and involve lymphocytes of all germinal centers and lymphoid tissues. Secretory IgA may also play a role in creating a noninflammatory host-microbial relationship as a consequence of its inability to fix the complement and the lack of proinflammatory IgA receptors on the intestinal macrophages.

\section{Pathogenesis of IgA Deficiency}

In IgA-deficient patients, the common finding is a maturation defect in B cells to produce IgA $[6,33]$. The defect appears to involve the stem cells since IgA deficiency can be transferred by bone marrow transplantation [34]. The constant $\alpha 1$ and $\alpha 2$ genes are generally normal except for rarely described cases of heavy chain gene deletions involving various segments on chromosome 14 [35]. This may be the case in sporadic IgA-deficient patients who have associated $\operatorname{IgG} 2$, IgG4, and IgE deficiencies [36-38]. In IgA deficiency, B cells express IgA; however, they are of immature phenotype with the coexpression of IgM and $\operatorname{IgD}$, and they cannot fully develop into IgA-secreting plasma cells $[39,40]$. An intrinsic B cell defect, T helper cell dysfunction, and suppressor $\mathrm{T}$ cells have all been reported in IgA deficiency. Abnormalities in the cytokine network such as lack of IL-4, IL-6, IL-7, IL-10, TGF- $\beta$, and most recently IL-21 have also been proposed to play a role in IgA deficiency [6, 41-43]. It is interesting that IL-21 stimulation has been shown to induce class switch recombination to $\operatorname{IgG}$ and $\operatorname{IgA}$ and differentiation of $\operatorname{IgA}$ and IG secreting plasma cells with restoration of immunoglobulin production ex vivo in patients with $\operatorname{IgA}$ deficiency and common variable immunodeficiency (CVID) [43].

There is a not well-defined genetic susceptibility in IgA deficiency. The pedigrees of $\operatorname{IgA}$-deficient individuals show familial clustering with no distinct Mendelian inheritance pattern. Autosomal recessive, autosomal dominant, and sporadic transmission patterns have all been observed [44]. In view of the variation in the inheritance patterns and the lack of an identified primary genetic defect, it is likely that IgA deficiency represents a heterogeneous group of genetic abnormalities such as CVID. Mutations in transmembrane activator and calcium-modulator and cyclophilin ligand interactor (TACI, TNFRSF13B) have been found both in a subset of patients with IgA deficiency or CVID [45]. TACI, B-cell surface ligand for BAFF and APRIL, has a role in isotype switching in B cells. The same TACI mutation may be present in individuals with either IgA deficiency or CVID in the same family. However, it is controversial whether TACI mutations have a cause-effect relationship with IgA deficiency or CVID [46, 47]. Recently, a shared cytotoxic T lymphocyte-associated protein-4-inducible costimulator risk locus in IgA deficiency and CVID has been defined [48]. It is also known that IgA deficiency may progress to CVID, supporting the notion that IgA deficiency and CVID lie in the spectrum of the same disease $[49,50]$.

Associations between IgA deficiency and certain major histocompatibility complex (MHC) class I, II, and III haplotypes have been proposed [6, 51-54]. In $\operatorname{IgA}$ deficiency and type 1 diabetes mellitus, HLA-B8 frequency was found to be increased in earlier studies. HLA-B8 frequency was also higher in $\operatorname{IgA}$ deficiency and autoimmune disorders. However, these findings may be secondary to the presence of diabetes mellitus or autoimmune disorders rather than IgA deficiency itself. In another study in IgA-deficient individuals, HLA B8 allele was not related to history of autoimmunity; however, IgA-deficient patients who had HLA B8 were found to have significantly higher pneumococcal vaccination responses [55]. A recent study questioning the frequently implied higher risk for IgA deficiency with the HLA8 DR3 haplotype has shown that IgA deficiency is not associated with a distinct haplotype; rather, the risk is conferred by the common extended MHC haplotype HLA A1, B8, DR3, and DQ2 (the 8.1 haplotype) acting in a multiplicative manner [56]. An amino acid substitution at position 57 of the HLA-DQ beta chain gene has also been associated with susceptibility to IgA deficiency [57].

\section{Epidemiology}

Selective IgA deficiency is considered as the most common primary immunodeficiency. The worldwide incidence 
varies depending on the ethnic background: $1: 143$ in the Arabian peninsula [58], 1:163 in Spain [59], 1:252 in Nigeria [60], 1:875 in England [61], and 1:965 in Brazil [62]. The incidence is lower among Asian populations, e.g., from $1: 2,600$ to $1: 5,300$ in China [63] and from $1: 14,840$ to $1: 18,500$ in Japan [64]. In general, IgA deficiency is more common in Caucasians. In the USA, the frequency is estimated to be from $1: 223$ to $1: 1,000$ in community studies and from 1:333 to 1:3,000 among healthy blood donors [6]. These numbers may in fact be higher because some individuals with IgA deficiency are asymptomatic, and there is no established routine screening program for IgA deficiency. The variation in incidence may also arise from the fact that the definition of selective IgA deficiency may differ in each study or registry.

\section{Clinical Manifestations}

There is a wide spectrum of clinical findings in $\operatorname{IgA}$ deficiency. Patients with IgA deficiency may be identified among blood bank donors, without any clinical findings [6]. In fact, $85-90 \%$ of IgA-deficient individuals are asymptomatic. This high percentage is interesting and still remains a puzzle to be solved since IgA is such a significant immunoglobulin in immune defense. Some patients with IgA deficiency have a tendency to develop recurrent sinopulmonary infections, gastrointestinal infections and disorders, allergies, autoimmune conditions, and malignancies.

Recurrent Sinopulmonary Infections Infections of the respiratory system are the most common findings in individuals with IgA deficiency $[6,55,65]$. These infections are mostly due to bacteria, e.g., Haemophilus influenzae and Streptococcus pneumoniae. Some patients may develop end organ damage such as bronchiectasis secondary to recurring or chronic infections [66]. Patients with associated antibody deficiency such as IgG2 subclass deficiency have a higher chance of having more severe infections and complications.

Gastrointestinal Infections/Disorders IgA-deficient individuals have a tendency to develop infections and disorders of the gastrointestinal tract $[6,44,55]$. Giardiasis, malabsorption, lactose intolerance, celiac disease, ulcerative colitis, nodular lymphoid hyperplasia, and malign proliferation are among the associated diseases. Since the protective barrier of the gastrointestinal system is impaired in $\operatorname{IgA}$ deficiency, protozoa such as Giardia lamblia can adhere to the epithelium, proliferate, and cause infection [67]. Malabsorption may ensue secondary to structural damage to the intestinal villi. Even in the absence of infection, some molecules may enter the subepidermal and submucosal tissue because of the impaired mucosal clearance of macromolecules and proteins. This process may facilitate antibody production against certain antigens and intolerance to certain foods [68]. For instance, patients with IgA deficiency have a higher chance of developing celiac disease [69]. Patients with IgA deficiency are not expected to develop IgA isotype antibodies against gliadin, tissue transglutaminase, or endomysium; however, they may have $\mathrm{IgG}$ isotype antibodies against those antigens. Inflammatory bowel diseases, mostly ulcerative colitis, have also been reported in association with selective IgA deficiency $[6,55,70,71]$.

Allergic Disorders Allergic disorders appear to be common in patients with IgA deficiency $[6,55,65]$. The reported frequency of allergies varies according to the definitions of both $\operatorname{IgA}$ deficiency and allergy and also by the evaluation methods. In an earlier study, atopy was reported in 58\% of pediatric and adult patients with $\operatorname{IgA}$ deficiency [72]. However, in a later study that surveyed $127 \operatorname{IgA}$-deficient patients between ages of 2 and 67 years, 13\% of patients, a figure which was probably not higher than in the general population, was noted to have a history of allergy and asthma [55]. History of allergy was more common among younger patients (median age 10.5 years). In 126 Brazilian children and adolescents with IgA deficiency, 48\% had respiratory allergies and atopic dermatitis [70]. In a recent prospective Swedish study in children, IgA-deficient patients were found to have an increased risk of pseudocroup at year 1 and parentally reported food hypersensitivity at year 4, both of which were possibly not IgE-mediated, as compared to children with normal serum levels of $\operatorname{IgA}$ [65]. In a more recent report, in which allergy status was determined more reliably by clinical presentation and skin prick testing using 14 common standard allergens, allergic manifestations including asthma, atopic dermatitis, allergic rhinitis/ conjunctivitis, urticaria, drug allergy, and food allergy were noted in $84 \%$ of patients (age range $4-32$ years) with selective IgA deficiency [71]. In $40.5 \%$ of the patients, allergic manifestations were the presenting symptoms. It is thought that $25 \%$ of patients with $\operatorname{IgA}$ deficiency are identified during evaluation for allergic disorders [6].

Autoimmunity Autoimmune diseases are among the most important clinical manifestations in $\operatorname{IgA}$ deficiency $[6,55$, 70]. Autoantibodies, such as antibodies against sulfatide, Jo-1, cardiolipin, phosphatidylserine, and collagen can be detected in IgA-deficient patients even if overt clinical disease is not the case [73]. It has been long known that several autoimmune disorders may occur in association with IgA deficiency. In a 2004 study, the second most common association with IgA deficiency after recurrent infections was autoimmunity (28\%) [55]. Autoimmunity was more prevalent in adults (median age 29 years) and in 
females (24 autoimmune conditions in females versus 14 in males in a total of 34 subjects). The most common autoimmune condition was idiopathic thrombocytopenic purpura followed by hemolytic anemia, juvenile rheumatoid arthritis, thyroiditis, systemic lupus erythematosus, and presence of various autoantibodies. In a younger population, autoimmune disorders, i.e., thyroid disease, arthropathy, celiac disease, anemia, and systemic lupus erythematosus, were detected in $19 \%$ of patients. This figure varies from $20 \%$ to $30 \%$ based on the age range of studied populations $[71,74]$. In addition, autoimmune conditions were found to be higher among relatives of IgA-deficient patients. Of the first-degree relatives of IgA-deficient patients, $10 \%$ had autoimmunity compared to an estimate of $5 \%$ in the general population.

IgA-deficient patients may develop anti-IgA antibodies which have a potential to cause anaphylactic reactions upon transfusion of any blood product, such as red blood cells or platelets, which contains trace amounts of $\operatorname{IgA}[75,76]$. The anti-IgA antibody capable of causing a type I hypersensitivity reaction would be of IgE isotype. Therefore, testing for the $\operatorname{IgE}$ isotype antibodies against IgA would be meaningful in determining the possibility of a blood transfusion reaction in an IgA-deficient patient. However, this testing is not readily available in most of the laboratories. Instead, IgG anti-IgA antibodies may be measured as a screening tool.

Malignancy The association of IgA deficiency and malignancies have been reported in sporadic cases, particularly at older ages. Those are usually of lymphoid and gastrointestinal origins $[55,77]$.

\section{Laboratory Evaluation}

IgA deficiency should be a consideration in a patient with recurrent respiratory and gastrointestinal infections, allergies, and autoimmune disorders [1, 2]. Immunologic evaluation for IgA deficiency is also warranted in case of anaphylaxis secondary to a blood product transfusion, celiac disease, and a family history of IgA deficiency and/ or CVID. It would be prudent to take into account the medications that may cause decreased serum levels of IgA in the patient. Evaluation of a suspected IgA deficiency would generally include a complete blood count with differential, quantitative serum immunoglobulin levels, serum IgG subclasses, specific antibody response to protein and polysaccharide antigens, and lymphocyte subsets. In addition, pertinent laboratory testing for the associated conditions, e.g., recurrent infections, allergies, or celiac disease, should be performed. Celiac disease screening should include $\mathrm{IgG}$ isotype antibodies against gliadin and tissue transglutaminase since $\operatorname{IgA}$ isotype antibodies may not be detected because of the IgA deficiency.

\section{Management}

IgA-deficient patients who are diagnosed coincidentally and/ or who do not have any symptoms do not need any treatment. However, awareness and education are of prime importance, particularly to prevent a potential anaphylactic reaction secondary to blood transfusion. In this regard, patients with selective IgA deficiency should be recommended to wear a medical alert bracelet. In case of a blood transfusion requirement, the patient, ideally, should be screened for anti-IgA antibodies. The blood product should be prepared from an IgA-deficient individual, or saline-washed red blood cells should be the choice. All blood products should be given with caution, and the staff should be prepared to treat a potential anaphylactic reaction.

In IgA deficiency, the mainstay of treatment is the treatment of associated diseases. If the patient experiences recurrent infections, daily prophylactic antibiotics on a continuous or seasonal intermittent basis may be beneficial. In case of associated $\operatorname{IgG}$ subclass deficiency and/or specific antibody deficiency, immunoglobulin treatment via venous or subcutaneous route with a product that contains minimal IgA may be given. Standard treatment approach is entertained in case of an associated allergic disorder or autoimmune condition.

\section{Prognosis}

The prognosis is good in patients with IgA deficiency if it is not associated with a significant disease. IgA deficiency in children may resolve over time. However, it is also known that $\operatorname{IgA}$ deficiency may progress into CVID, which has a less favorable outcome. Therefore, a patient with IgA deficiency, once identified, would deserve a regular follow-up of clinical and immunological findings.

In summary, although IgA deficiency is the most common primary immunodeficiency recognized for almost a half century, its genetic basis remains to be defined, and the cellular and molecular mechanisms involved in IgA physiology and functions as well as in disease pathogenesis need to be further elucidated. Molecular mechanisms of physiological and pathological actions are discussed in the accompanying review by Dr. Renato Monteiro.

Open Access This article is distributed under the terms of the Creative Commons Attribution Noncommercial License which per- 
mits any noncommercial use, distribution, and reproduction in any medium, provided the original author(s) and source are credited.

\section{References}

1. Conley ME, Notarangelo LD, Etzioni A. Diagnostic criteria for primary immunodeficiencies. Representing PAGID (Pan-American Group for Immunodeficiency) and ESID (European Society for Immunodeficiencies). Clin Immunol. 1999;93:190-7.

2. Geha RS, Notarangelo LD, Casanova JL, Chapel H, Conley ME, Fischer A, et al. Primary immunodeficiency diseases: an update from the International Union of Immunological Societies Primary Immunodeficiency Diseases Classification Committee. J Allergy Clin Immunol. 2007;120:776-94.

3. Grabar P, Williams CA. Method permitting the combined study of the electrophoretic and the immunochemical properties of protein mixtures; application to blood serum. Biochim Biophys Acta. 1953;10:193-4.

4. Mestecky J, McGhee JR. Immunoglobulin A ( $\operatorname{IgA})$ : molecular and cellular interactions involved in $\operatorname{IgA}$ biosynthesis and immune response. Adv Immunol. 1987;40:153-245.

5. Kerr MA. The structure and function of human IgA. Biochem J. 1990;271:285-96.

6. Cunningham-Rundles C. Physiology of IgA and IgA deficiency. J Clin Immunol. 2001;21:303-9.

7. Woof JM, Kerr MA. The function of immunoglobulin A in immunity. J Pathol. 2006;208:270-82.

8. Corthésy B. Roundtrip ticket for secretory IgA: role in mucosal homeostasis? J Immunol. 2007;178:27-32.

9. Monteiro RC, Kubagawa H, Cooper MD. Cellular distribution, regulation, and biochemical nature of an $\mathrm{Fc}$ alpha receptor in humans. J Exp Med. 1990;171:597-613.

10. Conley ME, Delacroix DL. Intravascular and mucosal immunoglobulin A: two separate but related systems of immune defense? Ann Intern Med. 1987;106:892-9.

11. Russell MW, Sibley DA, Nikolova EB, Tomana M, Mestecky J. IgA antibody as a non-inflammatory regulator of immunity. Biochem Soc Trans. 1997;25:466-70.

12. Mestecky J, Russell MW. Mucosal immunoglobulins and their contribution to defence mechanisms: an overview. Biochem Soc Trans. 1997;25:457-62.

13. Macpherson AJ, McCoy KD, Johansen FE, Brandtzaeg P. The immune geography of IgA induction and function. Mucosal Immunol. 2008;1:11-22.

14. Mostov KE, Deitcher DL. Polymeric immunoglobulin receptor expressed in MDCK cells transcytoses IgA. Cell. 1986;46:613-21.

15. Cerutti A, Rescigno M. The biology of intestinal immunoglobulin A responses. Immunity. 2008;28:740-50.

16. Fagarasan S. Evolution, development, mechanism and function of IgA in the gut. Curr Opin Immunol. 2008;20:170-7.

17. Suzuki K, Fagarasan S. How host-bacterial interactions lead to IgA synthesis in the gut. Trends Immunol. 2008;29:523-31.

18. Bäckhed F, Ley RE, Sonnenburg JL, Peterson DA, Gordon JI. Host-bacterial mutualism in the human intestine. Science. 2005;307:1915-20.

19. Tlaskalova-Hogenova H, Tuckova L, Mestecky J, Kolinska J, Rossmann P, Stepankova R, et al. Interaction of mucosal microbiota with the innate immune system. Scand J Immunol. 2005;62(Suppl 1):106-13

20. Macpherson AJ, Geuking MB, McCoy KD. Immune responses that adapt the intestinal mucosa to commensal intestinal bacteria. Immunology. 2005;115:1531-62.

21. Frank DN, St Amand AL, Feldman RA, Boedeker EC, Harpaz N, Pace NR. Molecular-phylogenetic characterization of microbial community imbalances in human inflammatory bowel diseases Proc Natl Acad Sci USA. 2007;104:13780-5.

22. Royle L, Roos A, Harvey DJ, Wormald MR, van Gijlswijk-Janssen D, Redwan E-RM, et al. Secretory IgA N- and O-glycans provide a link between the innate and adaptive immune systems. J Biol Chem. 2003;278:20140-53.

23. Mestecky J, Russell MW. Specific antibody activity, glycan heterogeneity and polyreactivity contribute to the protective activity of S-IgA at mucosal surfaces. Immunol Lett. 2009;124:57-62.

24. Brandtzaeg P, Karlsson G, Hansson G, Petruson B, Björkander J, Hanson LA. The clinical condition of IgA-deficient patients is related to the proportion of IgD- and IgM-producing cells in their nasal mucosa. Clin Exp Immunol. 1987;67:626-36.

25. Klemola $T$. Immunohistochemical findings in the intestine of IgA-deficient persons: number of intraepithelial $\mathrm{T}$ lymphocytes is increased. J Pediatr Gastroenterol Nutr. 1988;7:537-43.

26. Mestecky J, Zikan J, Butler WT. Immunoglobulin $M$ and secretory immunoglobulin A: presence of a common polypeptide chain different from light chains. Science. 1971;171:1163-5.

27. Savilahti E. IgA deficiency in children. Immunoglobulin-containing cells in the intestinal mucosa, immunoglobulins in secretions and serum IgA levels. Clin Exp Immunol. 1973;13:395-406.

28. Low TL, Liu YS, Putnam FW. Structure, function, and evolutionary relationships of Fc domains of human immunoglobulins A, G, M, and E. Science. 1976;191:390-2.

29. Mellander L, Björkander J, Carlsson B, Hanson LA. Secretory antibodies in IgA-deficient and immunosuppressed individuals. J Clin Immunol. 1986;6:284-91.

30. Fagarasan S, Muramatsu M, Suzuki K, Nagaoka H, Hiai H, Honjo T. Critical roles of activation-induced cytidine deaminase in the homeostasis of gut flora. Science. 2002;298:1424-7.

31. Jiang HQ, Bos NA, Cebra JJ. Timing, localization, and persistence of colonization by segmented filamentous bacteria in the neonatal mouse gut depend on immune status of mothers and pups. Infect Immun. 2001;69:3611-7.

32. Suzuki K, Meek B, Doi Y, Muramatsu M, Chiba T, Honjo T, et al. Aberrant expansion of segmented filamentous bacteria in IgA-deficient gut. Proc Natl Acad Sci USA. 2004;101:1981-6.

33. Wang Z, Yunis D, Irigoyen M, Kitchens B, Bottaro A, Alt FW, et al. Discordance between IgA switching at the DNA level and IgA expression at the mRNA level in IgA-deficient patients. Clin Immunol. 1999;91:263-70.

34. Hammarström L, Lönnqvist B, Ringdén O, Smith CI, Wiebe T. Transfer of IgA deficiency to a bone-marrow-grafted patient with aplastic anaemia. Lancet. 1985;1:778-81.

35. Suzuki H, Kaneko H, Fukao T, Jin R, Kawamoto N, Asano T, et al. Various expression patterns of alpha1 and alpha2 genes in IgA deficiency. Allergol Int. 2009;58:111-7.

36. Plebani A, Carbonara AO, Bottaro A, Gallina R, Boccazzi C, Crispino $\mathrm{P}$, et al. Gene deletion as a cause of associated deficiency of $\operatorname{IgA} 1, \operatorname{IgG} 2, \operatorname{IgG} 4$ and $\operatorname{IgE}$. Immunodeficiency. $1993 ; 4: 245-8$.

37. Wiebe V, Helal A, Lefranc MP, Lefranc G. Molecular analysis of the T17 immunoglobulin $\mathrm{CH}$ multigene deletion (del A1-GP-G2G4-E). Hum Genet. 1994;93:520-8.

38. Levy Y, Nakum A, Segal N, Monselise Y, Danon YL. The association of selective IgA deficiency and IgE hypogammaglobulinemia. Allergy. 2005;60(6):836-8. No abstract available.

39. Lawton AR, Royal SA, Self KS, Cooper MD. IgA determinants on B-lymphocytes in patients with deficiency of circulating IgA. J Lab Clin Med. 1972;80:26-33.

40. Conley ME, Cooper MD. Immature IgA B cells in IgA-deficient patients. N Engl J Med. 1981;305:495-7.

41. Ramsay AJ, Husband AJ, Ramshaw IA, Bao S, Matthaei KI, Koehler $G$, et al. The role of interleukin-6 in mucosal IgA antibody responses in vivo. Science. 1994;264:561-3. 
42. Okahashi N, Yamamoto M, Vancott JL, Chatfield SN, Roberts M, Bluethmann $\mathrm{H}$, et al. Oral immunization of interleukin-4 (IL-4) knockout mice with a recombinant Salmonella strain or cholera toxin reveals that CD4+ Th2 cells producing IL-6 and IL-10 are associated with mucosal immunoglobulin A responses. Infect Immun. 1996;64:1516-25.

43. Borte S, Pan-Hammarström Q, Liu C, Sack U, Borte M, Wagner $\mathrm{U}$, et al. Interleukin-21 restores immunoglobulin production ex vivo in patients with common variable immunodeficiency and selective IgA deficiency. Blood. 2009;114:4089-98.

44. Hammarström L, Vorechovsky I, Webster D. Selective IgA deficiency (SIgAD) and common variable immunodeficiency (CVID). Clin Exp Immunol. 2000;120:225-31.

45. Castigli E, Wilson SA, Garibyan L, Rachid R, Bonilla F, Schneider $\mathrm{L}$, et al. TACI is mutant in common variable immunodeficiency and IgA deficiency. Nat Genet. 2005;37:829-34.

46. Pan-Hammarström Q, Salzer U, Du L, Björkander J, Cunningham-Rundles $\mathrm{C}$, Nelson DL, et al. Reexamining the role of TACI coding variants in common variable immunodeficiency and selective IgA deficiency. Nat Genet. 2007;39:429-30.

47. López-Mejías R, del Pozo N, Fernández-Arquero M, Ferreira A, García-Rodríguez MC, de la Concha EG, et al. Role of polymorphisms in the TNFRSF13B (TACI) gene in Spanish patients with immunoglobulin A deficiency. Tissue Antigens. 2009;74:42-5.

48. Haimila K, Einarsdottir E, de Kauwe A, Koskinen LL, PanHammarström Q, Kaartinen T, et al. The shared CTLA4-ICOS risk locus in celiac disease, $\operatorname{IgA}$ deficiency and common variable immunodeficiency. Genes Immun. 2009;10:151-61.

49. Español T, Catala M, Hernandez M, Caragol I, Bertran JM. Development of a common variable immunodeficiency in IgA-deficient patients. Clin Immunol Immunopathol. 1996;80:333-5.

50. Aghamohammadi A, Mohammadi J, Parvaneh N, Rezaei N, Moin M, Espanol T, et al. Progression of selective IgA deficiency to common variable immunodeficiency. Int Arch Allergy Immunol. 2008;147:87-92.

51. Van Thiel DH, Smith WI Jr, Rabin BS, Fisher SE, Lester R. A syndrome of immunoglobulin A deficiency, diabetes mellitus, malabsorption, a common HLA haplotype. Immunologic and genetic studies of forty-three family members. Ann Intern Med. 1977;86:10-9.

52. Cunningham-Rundles C, Fotino M, Rosina O, Peter JB. Selective IgA deficiency, IgG subclass deficiency, and the major histocompatibility complex. Clin Immunol Immunopathol. 1991;61:61-9.

53. Schroeder HW Jr, Zhu ZB, March RE, Campbell RD, Berney SM, Nedospasov SA, et al. Susceptibility locus for IgA deficiency and common variable immunodeficiency in the HLA-DR3, -B8, -A1 haplotypes. Mol Med. 1998;4:72-86.

54. De la Concha EG, Fernandez-Arquero M, Gual L, Vigil P, Martinez A, Urcelay E, et al. MHC susceptibility genes to IgA deficiency are located in different regions on different HLA haplotypes. J Immunol. 2002;169:4637-43.

55. Edwards E, Razvi S, Cunningham-Rundles C. IgA deficiency: clinical correlates and responses to pneumococcal vaccine. Clin Immunol. 2004;111:93-7.

56. Mohammadi J, Ramanujam R, Jarefors S, Rezaei N, Aghamohammadi A, Gregersen PK, Hammarström L. IgA deficiency and the MHC: assessment of relative risk and microheterogeneity within the HLA A1 B8, DR3 (8.1) haplotype. J Clin Immunol. 2009; in press PMID: 19834793.

57. Olerup O, Smith CI, Hammarström L. Different amino acids at position 57 of the HLA-DQ beta chain associated with susceptibility and resistance to IgA deficiency. Nature. 1990;347:289-90.
58. Al-Attas RA, Rahi AH. Primary antibody deficiency in Arabs: first report from eastern Saudi Arabia. J Clin Immunol. 1998;18:368-71.

59. Pereira LF, Sapina AM, Arroyo J, Viñuelas J, Bardají RM, Prieto L. Prevalence of selective IgA deficiency in Spain: more than we thought. Blood. 1997;90:893.

60. Ezeoke AC. Selective IgA deficiency (SIgAD) in eastern Nigeria. Afr J Med \& Med Sci. 1988;17:17-21.

61. Holt PD, Tandy NP, Anstee DJ. Screening of blood donors for IgA deficiency: a study of the donor population of south-west England. J Clin Pathol. 1977;30:1007-10.

62. Carneiro-Sampaio MM, Carbonare SB, Rozentraub RB, de Araújo MN, Riberiro MA, Porto MH. Frequency of selective IgA deficiency among Brazilian blood donors and healthy pregnant women. Allergol Immunopathol (Madr). 1989;17:213-6.

63. Feng L. Epidemiological study of selective IgA deficiency among 6 nationalities in China. Zhonghua Yi Xue Za Zhi. 1992;72:8890.

64. Kanoh T, Mizumoto T, Yasuda N, Koya M, Ohno Y, Uchino H, et al. Selective IgA deficiency in Japanese blood donors: frequency and statistical analysis. Vox Sang. 1986;50:81-6.

65. Janzi M, Kull I, Sjöberg R, Wan J, Melén E, Bayat N, et al. Selective IgA deficiency in early life: association to infections and allergic diseases during childhood. Clin Immunol. 2009;133:78-85.

66. Chipps BE, Talamo RC, Winkelstein JA. IgA deficiency, recurrent pneumonias, and bronchiectasis. Chest. 1978;73:519-26.

67. Zinneman HH, Kaplan AP. The association of giardiasis with reduced intestinal secretory immunoglobulin A. Am J Dig Dis. 1972;17:793-7.

68. Cunningham-Rundles C, Brandeis WE, Pudifin DJ, Day NK, Good RA. Autoimmunity in selective IgA deficiency: relationship to anti-bovine protein antibodies, circulating immune complexes and clinical disease. Clin Exp Immunol. 1981;45:299-304.

69. Meini A, Pillan NM, Villanacci V, Monafo V, Ugazio AG, Plebani A. Prevalence and diagnosis of celiac disease in IgA-deficient children. Ann Allergy Asthma Immunol. 1996;77:333-6.

70. Jacob CM, Pastorino AC, Fahl K, Carneiro-Sampaio M, Monteiro RC. Autoimmunity in IgA deficiency: revisiting the role of IgA as a silent housekeeper. J Clin Immunol. 2008;28:S56-61.

71. Aghamohammadi A, Cheraghi T, Gharagozlou M, Movahedi M, Rezaei N, Yeganeh M, et al. IgA deficiency: correlation between clinical and immunological phenotypes. J Clin Immunol. 2009;29:130-6.

72. Buckley RH. Clinical and immunologic features of selective $\operatorname{IgA}$ deficiency. Birth Defects Orig Artic Ser. 1975;11:134-42.

73. Barka N, Shen GQ, Shoenfeld Y, Alosachie IJ, Gershwin ME, Reyes $\mathrm{H}$, et al. Multireactive pattern of serum autoantibodies in asymptomatic individuals with immunoglobulin A deficiency. Clin Diagn Lab Immunol. 1995;2:469-72.

74. Jorgensen GH, Thorsteinsdottir I, Gudmundsson S, Hammarstrom L, Ludviksson BR. Familial aggregation of IgAD and autoimmunity. Clin Immunol. 2009;131:233-9.

75. Pineda AA, Taswell HF. Transfusion reactions associated with anti-IgA antibodies: report of four cases and review of the literature. Transfusion. 1975;15:10-5.

76. Cunningham-Rundles C, Zhou Z, Mankarious S, Courter S. Long-term use of IgA-depleted intravenous immunoglobulin in immunodeficient subjects with anti-IgA antibodies. J Clin Immunol. 1993;13:272-8.

77. Kersey JH, Shapiro RS, Filipovich AH. Relationship of immunodeficiency to lymphoid malignancy. Pediatr Infect Dis J. 1988;7: S10-2. 